\title{
Bacterial Infections in Patients with Liver Cirrhosis in an Internal Medicine Department
}

\author{
Cristina Lameirão Gomes Renata Violante Silva Paulo Carrola José Presa \\ Liver Unit, Internal Medicine Department, Centro Hospitalar de Trás-os-Montes e Alto Douro, Vila Real, Portugal
}

\section{Keywords}

Liver cirrhosis · Bacterial infections · Child-Pugh-Turcotte score $\cdot$ Model for End-Stage Liver Disease score

\section{Abstract}

Background and Aims: Liver cirrhosis (LC) is the end stage of multiple processes that lead to hepatic failure and is the 10th most common cause of death in the Western world. Bacterial infections are one of the most important clinical problems in patients with LC, as their underlying immune status is compromised. Approximately $60 \%$ of bacterial infections in cirrhotic patients are community acquired (CA) and $40 \%$ are nosocomial. The most common infections in cirrhotic patients are spontaneous bacterial peritonitis (SBP) (25\%), urinary tract infection (UTI) (20\%), pneumonia (15\%), bacteremia $(12 \%)$, and cellulitis $(2-11 \%)$. The aim of this study was to evaluate the most frequent infections in patients with $L C$ and describe the evolution of the microbiology in these patients. Material and Methods: This is a retrospective analysis of 4 interspersed years (2008, 2010, 2012, and 2014) that included 372 patients. Demographic characteristics were evaluated, including gender, age, type of infection, bacteria resistance profile, antibiotic use, Child-PughTurcotte and Model for End-Stage Liver Disease scores, and mortality rate. Results: The mean age of all patients enrolled in this study was $64.5 \pm 12.2$ years. Male patients were significantly more prevalent than female ones ( 72 vs. $28 \%$ ). In the 4 analyzed years, the following numbers of infections occurred: 71 infections (49\% CA and 51\% nosocomial) in 2008; 86 infections (60.5\% CA and $39.5 \%$ nosocomial) in 2010; 99 infections (56.6\% CA and $43.4 \%$ nosocomial) in 2012; and 116 infections (70.7\% CA and 29.3\% nosocomial) in 2014. The most frequent infections were UTI (32.5\%), respiratory tract infection (29.3\%), SBP (26.1\%), and cellulitis (6.2\%). A microbiological agent was identified in 32.4, 59.3, 53.5 , and $61.2 \%$ of infections in 2008, 2010,2012, and 2014, respectively, with a predominance of gram-negative bacilli. In all series, a third-generation cephalosporin was the most frequent antibiotic used empirically. The majority of patients was in stage $B(42.7 \%)$ of the Child-Pugh-Turcotte score, followed by stage C (39.3\%) and stage A (18\%). Mortality increased significantly over the years, from $7 \%$ in 2008 to $25 \%$ in $2014(p=0.016)$. Conclusions: The present study showed a high prevalence of bacterial infections in patients with LC. A high rate of suspicion is needed for an infectious process in these patients, and an appropriate antibiotic treatment can decrease the morbidity and mortality in cirrhotic patients.

(c) 2018 Sociedade Portuguesa de Gastrenterologia Published by S. Karger AG, Basel

\section{KARGER}

E-Mail karger@karger.com www.karger.com/pjg
(C) 2018 Sociedade Portuguesa de Gastrenterologia Published by S. Karger AG, Basel

Karger

Open access

This article is licensed under the Creative Commons AttributionNonCommercial-NoDerivatives 4.0 International License (CC BYNC-ND) (http://www.karger.com/Services/OpenAccessLicense). Usage and distribution for commercial purposes as well as any distribution of modified material requires written permission.
Cristina Lameirão Gomes

Centro Hospitalar de Trás-os-Montes e Alto Douro

Av. Da Noruega, Lordelo

Vila Real 5000-508 (Portugal)

E-Mail cristinasofiagomes@ hotmail.com 
Infeções bacterianas em doentes com cirrose hepática num serviço de medicina interna

\author{
Palavras Chave \\ Cirrose hepática $\cdot$ Infeções bacterianas . \\ Child-Pugh-Turcotte score · Model for End-Stage Liver \\ Disease score
}

\section{Resumo}

Introdução: A cirrose hepática $(\mathrm{CH})$ é o estágio final de múltiplos processos que conduzem à insuficiência hepática e corresponde à $10^{\text {a }}$ causa de morte mais comum no mundo Ocidental. As infeções bacterianas são uma complicação frequente nos doentes com $\mathrm{CH}$, devido ao seu estado de imunossupressão. Aproximadamente $60 \%$ das infeções bacterianas em cirróticos são adquiridas na comunidade $(A C)$ e $40 \%$ são nosocomiais. As infeções bacterianas mais comuns em cirróticos são Peritonite Bacteriana Espontânea (PBE) (25\%), Infeção do Trato Urinário (ITU) (20\%), Pneumonia (15\%), Bacteriemia (12\%) e Celulite (2-11\%). O objetivo deste estudo é avaliar as infeções mais frequentes em doentes com $\mathrm{CH}$ e descrever a evolução da microbiologia nos mesmos. Material e Métodos: Análise retrospetiva de quatro anos intercalados (2008, 2010, 2012 e 2014) que incluiu trezentos e setenta e dois doentes. Características demográficas: género, idade, tipo de infeção, perfil de resistência bacteriana, uso de antibióticos, scores Child-Pugh-Turcotte e Model for End-Stage Liver Disease e taxa de mortalidade. Resultados: A idade média dos doentes incluídos neste estudo foi de $64.5 \pm 12.2$ anos. Os homens foram, significativamente, mais prevalentes que as mulheres (72 vs. $28 \%$ ). Nos quatro anos intercalados, ocorreram: 71 infeções (49\% AC e 51\% nosocomiais) em 2008; 86 infeções (60.5\% AC e $39.5 \%$ nosocomiais) em 2010; 99 infeções (56.6\% AC e 43.4\% nosocomiais) em 2012 e 116 infeções (70.7\% AC e $29.3 \%$ nosocomiais) em 2014. As infeções mais frequentes foram a ITU (32.5\%), Infeção do Trato Respiratório (29.3\%), PBE (26.1\%) e Celulite (6.2\%). Identificou-se o agente microbiológico em 32.4, 59.3, 53.5 e 61.2\% das infeções em 2008, 2010, 2012 e 2014, respetivamente, com predomínio de bacilos Gram-negativos. Em todas as séries, as cefalosporinas de terceira geração foram o antibiótico mais utilizado empiricamente. A grande maioria dos doentes encontra-se no estadio B (42,7\%) do score Child-Pugh-Turcotte, seguido de C (39.3\%) e A (18\%). A mortalidade aumentou, significativamente, de 7\% em 2008 para 25\% em 2014 $(p=0.016)$. Conclusões: O presente estudo mostrou uma

Bacterial Infections in Patients with Liver Cirrhosis elevada prevalência de infeções bacterianas em doentes com $\mathrm{CH}$. É necessário uma alta suspeita clínica para infeção nestes doentes, pois o tratamento antibiótico precoce e apropriado pode diminuir a morbilidade e a mortalidade.

(C) 2018 Sociedade Portuguesa de Gastrenterologia Publicado por S. Karger AG, Basel

\section{Introduction}

Liver cirrhosis is a progressive disease that evolves from a compensated stage (mostly asymptomatic) to a decompensated stage [1]. The decompensated stage occurs when the complications of cirrhosis appear (upper gastrointestinal bleeding, ascites, hepatic encephalopathy, or hepatorenal syndrome) [1]. The risk of death in compensated cirrhosis is 4.7 times higher than in the general population, and in decompensated cirrhosis, the risk of death is 9.7 times higher [2]. Liver cirrhosis is the 10th most common cause of death in the Western world [3]. Bacterial infections are one of the most important clinical problems in patients with decompensated liver cirrhosis, particularly in hospitalized patients, and they are associated with high morbidity and mortality rates [4-6]. Infections in cirrhotic patients are either present at admission or develop during hospitalization in about $20-35 \%$ of patients in some series or $20-60 \%$ of patients in others $[3,4,7]$. Ninety percent of the cirrhotic patients' infections are bacterial [5]. The in-hospital mortality of cirrhotic patients with infections is about 15\% (2 times higher than in cirrhotic patients without infection), but it can increase to $70 \%$ if a septic shock occurs $[5,8]$. The most common infections in cirrhotic patients are spontaneous bacterial peritonitis (SBP) (25\%), urinary tract infection (UTI) (20\%), pneumonia (15\%), bacteremia $(12 \%)$, and cellulitis $(2-11 \%)[5,8]$. Clinical factors associated with an increased risk of infection are deterioration of liver function, variceal bleeding, prior SBP, low ascitic fluid protein levels, and hospitalization $[7,9]$. The mechanisms underlying the pathogenesis of bacterial infections are gut microbiota, intestinal permeability, bacterial translocation, and immune deficiency $[8,9]$. Infections are culture positive in $50-70 \%$ of cases [8]. In a significant proportion of patients, bacterial infections are caused by gram-negative bacteria, even though the incidence of gram-positive bacteria has been increasing, during the last decade, due to the improvement in the management of liver cirrhosis with the increased use of invasive procedures and extended use of antibiotic prophylaxis (mainly norfloxacin) $[3,4,9]$. Nevertheless, in 
recent years, gram-negative bacteria have been re-emerging as a cause of bacterial infections in cirrhotic patients as a consequence of multiple improvements in the whole hospital setting [3].

The objectives of this study are (1) to identify the most frequent infections in patients with liver cirrhosis; (2) to describe the evolution of microbiology in infections occurring in hospitalized patients with cirrhosis; and (3) to characterize the population according to gender, age, type of infection, bacteria resistance profile, antibiotic use, Child-Pugh-Turcotte (CPT) and Model for EndStage Liver Disease (MELD) scores, and mortality rate.

\section{Material and Methods}

This study was a retrospective analysis of the microbiology data evaluation of patients with liver cirrhosis admitted to the medical ward of the Internal Medicine Department due to infection or with infection developing during hospitalization during 4 interspersed years $(2008,2010,2012$, and 2014).

We obtained a list of all hospitalized patients diagnosed with liver cirrhosis in 2008, 2010, 2012, and 2014. A list of 219 hospitalizations of patients with liver cirrhosis was provided in 2008, of 204 patients in 2010, of 228 patients in 2012, and of 313 patients in 2014. Then, we checked process by process to see which patients were admitted to the medical ward of the Internal Medicine Department with an infection and which patients developed an infectious process during hospitalization. So, we included in this study 71 infections in 2008, 86 infections in 2010, 99 infections in 2012, and 116 infections in 2014, excluding all patients who were admitted for other complications of liver cirrhosis (e.g., upper gastrointestinal bleeding, hepatic encephalopathy, or hepatorenal syndrome). In this study, we only included admissions caused by infections or patients who developed infections during hospitalization.

The aim of this study was to evaluate the microbiology of patients with liver cirrhosis admitted to the medical ward of the Internal Medicine Department and to verify if at our hospital, over the years, the prevalence of gram-negative bacteria remained the same or if there was an increase in gram-positive bacteria. We also examined the prevalence of hospital mortality in patients with liver cirrhosis, associated with infection, at our hospital.

\section{Definitions}

Cirrhosis is the irreversible fibrosis of the liver, the end stage of a final shared pathway in chronic damage to a major vital organ [2]. Liver cirrhosis is a progressive disease that evolves from a compensated stage (mostly asymptomatic) to a decompensated stage [1].

Bacterial infection is common and accounts for the major morbidity and mortality in cirrhosis [6]. Patients with cirrhosis are immunocompromised and have increased susceptibility to developing spontaneous bacterial infections or hospital-acquired infections [6]. Infections in cirrhotic patients are either present at admission or develop during hospitalization in about $20-35 \%$ of patients in some series or $20-60 \%$ of patients in others $[3,4,7]$.
Bacterial resistance is the capacity of bacteria to withstand the effects of antibiotics or biocides that are intended to kill or control them. "Multiresistant bacteria" is a term that is used when a bacterial strain is resistant to several different antimicrobials or antimicrobial classes (e.g., $\beta$-lactamase-producing Enterobacteriaceae) [10].

\section{Patients}

We divided the patients into 2 categories of infections according to the most recent recommendations:

- Community acquired (CA): infections diagnosed in the first $48 \mathrm{~h}$ of hospital admission, in patients without hospitalization within the previous 90 days.

- Nosocomial: infections diagnosed in patients with more than $48 \mathrm{~h}$ of hospitalization.

\section{Statistical Analysis}

We performed the appropriate statistical analysis with the software package IBM SPSS Statistics (version SPSS software 20.0, SPSS Inc., 2011, Chicago, IL, USA) and evaluated statistical significance using different methods depending on the normalization of the data. Frequency differences were assessed using the $\chi^{2}$ test. The normality of continuous variables was evaluated by graphical analysis of histogram, boxplot, and Q-Q plot. Variables with normal distribution were described by means \pm standard deviations, and the variables with non-normal distribution were described by medians and 25th and 75th percentiles (P25-P75). Comparisons between groups were made using the $t$ test for 2 independent samples and the Mann-Whitney test, respectively. The threshold for significance was defined as $p<0.05$.

\section{Results}

\section{Patient Infections}

In the present study, we included patients with liver cirrhosis hospitalized in the medical ward for infection in 4 different periods: 71 infections in 58 patients in 2008, including 35 (49\%) CA and 36 (51\%) nosocomial; 86 infections in 65 patients in 2010, including $52(60.5 \%) \mathrm{CA}$ and 34 (39.5\%) nosocomial; 99 infections in 65 patients in 2012, including 56 (56.6\%) CA and 43 (43.4\%) nosocomial; and 116 infections in 87 patients in 2014, including $82(70.7 \%)$ CA and $34(29.3 \%)$ nosocomial. In all periods, the patients were mostly men, $77.5 \%$ in $2008,62.8 \%$ in $2010,78 \%$ in 2012 , and $69.8 \%$ in 2014 , with no statistically significant differences regarding the ratio of men/ women among the 4 groups $(p=0.088)$. In 2014, the patients were significantly older (mean 68.1 years [standard deviation 11.75], $p<0.001$ ) than in previous periods. The characteristics of the patients are described in Table 1 .

In the 4 periods, the most prevalent etiology of cirrhosis was alcoholic, with no significant differences between groups ( $p=0.667)$. However, there were various etiologies of cirrhosis, as described in Table 1. 
Table 1. Characteristics of patients with liver cirrhosis according to the year of hospitalization

\begin{tabular}{|c|c|c|c|c|c|}
\hline & $2008(n=71)^{\mathrm{e}}$ & $2010(n=86)^{\mathrm{e}}$ & $2012(n=99)^{\mathrm{e}}$ & $2014(n=116)^{\mathrm{e}}$ & $p$ value \\
\hline Female gender, $n(\%)$ & $16(22.5)$ & $32(37.2)$ & $22(22.0)$ & $35(30.2)$ & $0.088^{\mathrm{a}}$ \\
\hline Age, years, mean (SD) & $63.0(11.41)$ & $61.2(12.86)$ & $64.3(11.85)$ & $68.1(11.75)$ & $<0.001^{\mathrm{b}}$ \\
\hline $\begin{array}{l}\text { Duration of hospitalization, } \\
\text { days, mean (SD) }\end{array}$ & $13.5(11.4)$ & $15.8(12.4)$ & $11.9(8.3)$ & $14.7(10.9)$ & $0.082^{\mathrm{c}}$ \\
\hline \multicolumn{6}{|l|}{ Etiology, $n(\%)$} \\
\hline Alcoholic & $58(81.7)$ & $75(87.2)$ & $91(91.92)$ & $100(86.1)$ & \\
\hline $\mathrm{HCV}$ & $5(7.1)$ & $5(5.8)$ & $1(1.01)$ & $3(2.6)$ & \\
\hline $\mathrm{HBV}$ & - & $1(1.2)$ & - & $2(1.7)$ & \\
\hline Alcoholic + virus & $5(7.0)$ & $2(2.3)$ & $2(2.02)$ & $4(3.5)$ & \\
\hline Others ${ }^{\mathrm{d}}$ & $2(2.8)$ & $2(2.3)$ & $3(3.03)$ & $6(5.2)$ & \\
\hline Cryptogenic & $1(1.4)$ & $1(1.2)$ & $2(2.02)$ & $1(0.9)$ & $0.667^{\mathrm{a}}$ \\
\hline \multicolumn{6}{|l|}{ Infection origin, $n(\%)$} \\
\hline Community acquired & $35(49.0)$ & $52(60.5)$ & $56(56.6)$ & $82(70.7)$ & \\
\hline Nosocomial & $36(51.0)$ & $34(39.5)$ & $43(43.4)$ & $34(29.3)$ & $0.024^{\mathrm{a}}$ \\
\hline \multicolumn{6}{|l|}{ Origin, $n(\%)$} \\
\hline Emergency department & $58(81.7)$ & $76(88.4)$ & $91(91.92)$ & $108(93.1)$ & \\
\hline External consultation & $7(9.9)$ & $3(3.5)$ & $4(4.04)$ & $8(6.9)$ & \\
\hline Intensive care unit & $3(4.2)$ & $1(1.2)$ & $2(2.02)$ & - & \\
\hline Hepatology day hospital & $2(2.8)$ & - & - & - & \\
\hline Another hospital & $1(1.4)$ & $2(2.3)$ & $2(2.02)$ & - & \\
\hline \multicolumn{6}{|c|}{ Child-Pugh-Turcotte score, $n(\%)$} \\
\hline A & $10(14.1)$ & $21(24.4)$ & $18(18.2)$ & $18(18.4)$ & \\
\hline $\mathrm{B}$ & $31(43.7)$ & $28(32.8)$ & $44(44.4)$ & $58(50)$ & \\
\hline $\mathrm{C}$ & $30(42.3)$ & $37(43.0)$ & $37(37.4)$ & $40(34.5)$ & $0.066^{\mathrm{a}}$ \\
\hline MELD, median (P25-P75) & $17(12.5-20.5)$ & $21(14.0-23.0)$ & $16(12.2-18.0)$ & $14(11.0-19.0)$ & $0.001^{\mathrm{c}}$ \\
\hline Mortality, $n(\%)$ & $5(7.0)$ & $15(17.4)$ & $15(15.2)$ & $29(25.0)$ & $0.016^{\mathrm{a}}$ \\
\hline
\end{tabular}

HCV, hepatitis C virus; HBV, hepatitis B virus; $n$, total number of patients; SD, standard deviation; MELD, Model for End-Stage Liver Disease score; P25-P75, 25th and 75th percentiles. ${ }^{a} \chi^{2}$ test. ${ }^{\mathrm{b}} t$ test for independent samples. ${ }^{\mathrm{c}}$ Mann-Whitney test. ${ }^{\mathrm{d}}$ Primary biliary cholangitis, nonalcoholic steatohepatitis, autoimmune hepatitis, and a1-antitrypsin deficiency. ${ }^{\mathrm{e}} n$ indicates number of infections.

The average duration of hospitalization was $13.5 \pm$ 11.4 days in $2008,15.8 \pm 12.4$ days in $2010,11.9 \pm 8.3$ days in 2012 and $14.7 \pm 10.9$ days in 2014 , with no statistically significant differences between the years $(p=0.082)$.

The majority of patients was in stage B (42.7\%) of the CPT score (except in 2010), followed by stage C (39.3\%) and stage A (18\%). The median severity score in patients with hepatic cirrhosis (MELD) was lower in the recent periods (16.0 [P25 12.2 and P75 18.0] and 14.0 [P25 11.0 and $P 75$ 19.0] in 2012 and 2014, respectively) than in previous periods (17.0 [P25 12.5 and P75 20.5] and 21.0 [P25 14.0 and $P 75$ 23.0] in 2008 and 2010, respectively). In the 4 periods, the most frequent infections were SBP, UTI, respiratory tract infection, and cellulitis. In 2008, the most prevalent infection was SBP (38.0\%), while in the remaining periods the most prevalent infection was that of the urinary tract. However, we found a variety of infections in cirrhotic patients, as shown in Table 2.

A microbiological agent was identified in $32.4,59.3$, 53.5 , and $61.2 \%$ of infections in 2008, 2010, 2012, and 2014 , respectively. In fact, we were able to recognize 23 bacteria in 2008, including 10 (43.5\%) gram-negative and 13 (56.5\%) gram-positive bacteria; 51 bacteria in 2010, including 31 (60.8\%) gram-negative and 20 (39.2\%) gram-positive bacteria; 53 microbiological agents in 2012, including 35 (66.0\%) gram-negative bacteria, 16 (30.2\%) gram-positive bacteria, and 2 (3.8\%) fungi; and 71 microbiological agents in 2014, including 48 (67.6\%) gramnegative and 23 (32.4\%) gram-positive bacteria.

The majority of microbiological agents identified were Escherichia coli. In 2012, we isolated 2 fungi (Candida albicans): both were isolated in uroculture, caused by UTI. 
Table 2. Type of infections in cirrhotic patients

\begin{tabular}{lrrrr}
\hline & 2008 & 2010 & 2012 & 2014 \\
\hline Spontaneous bacterial peritonitis & 27 & 22 & 24 & 24 \\
Urinary tract infection & 10 & 31 & 38 & 42 \\
Respiratory tract infection & 24 & 20 & 24 & 41 \\
Cellulitis & 4 & 5 & 8 & 6 \\
Spontaneous bacterial empyema & 1 & - & - & 2 \\
Acute gastroenteritis & - & 2 & 1 & - \\
Bacteremia & 4 & 4 & - & - \\
Phlebitis & - & 1 & 2 & - \\
Mumps & 1 & - & - & - \\
Cutaneous wound & - & 1 & - & - \\
Brucellosis & - & - & 1 & - \\
Malaria & - & - & 1 & - \\
Meningitis (Neisseria meningitidis) & - & - & - & 1 \\
\hline
\end{tabular}

However, we found a great variety in microbiological agents in cirrhotic patients, as shown in Table 3 and 4 .

Also, in our research, we found some resistant bacteria throughout the years. In 2008, we identified 7 (9.6\%) resistant bacteria: 1 (14.3\%) CA and $6(85.7 \%)$ nosocomial. In 2010, we found 17 (18.5\%) resistant bacteria: 5 (29.4\%) CA and 12 (70.6\%) nosocomial. In 2012, we identified 12 (11.3\%) multiresistant bacteria: 3 (25\%) CA and 9 (75\%) nosocomial. In 2014, we found 18 (14.4\%) resistant bacteria: 3 (16.7\%) CA and 15 (83.3\%) nosocomial.

In all periods, a third-generation cephalosporin (ceftriaxone) was the most frequent antibiotic used empirically: 34 (50\%) patients used it in 2008, $33(42.8 \%)$ in $2010,41(42.3 \%)$ in 2012 , and $59(43 \%)$ in 2014 , followed by amoxicillin/clavulanate with increased use over time (13.1\% in $2008,17.1 \%$ in $2010,20.3 \%$ in 2012 , and $21.6 \%$ in 2014) in association with the increase in urinary and respiratory tract infections (the latter being sometimes associated with macrolides). In Table 5, the various antibiotics used are summarized. In all series, the efficacy of antibiotic therapy was high $(77.5 \%$ in $2008,66.3 \%$ in $2010,70.7 \%$ in 2012 , and $75 \%$ in 2014 ). However, the mortality rate increased significantly over time, from $7 \%$ in 2008 to $25 \%$ in 2014 , with significant differences between all series $(p=0.016)$.

\section{Discussion}

The association between cirrhosis and bacterial infections has been investigated intensively for a long time [11]. Cirrhotic patients are prone to develop infectious diseases because of their underlying immune-compro-
Table 3. Identification of gram-negative bacteria in cirrhotic patients

\begin{tabular}{|c|c|c|c|c|}
\hline & 2008 & 2010 & 2012 & 2014 \\
\hline \multicolumn{5}{|l|}{ Escherichia coli } \\
\hline Multisensitive & 3 & 13 & 15 & 13 \\
\hline Resistant (ESBL) & $-(-)$ & $7(2)$ & $3(6)$ & $2(9)$ \\
\hline \multicolumn{5}{|l|}{ Klebsiella pneumoniae } \\
\hline Multisensitive & 1 & 3 & 3 & 3 \\
\hline Resistant (ESBL) & $1(-)$ & $1(-)$ & $-(-)$ & $-(2)$ \\
\hline \multicolumn{5}{|l|}{ Pseudomonas aeruginosa } \\
\hline Multisensitive & 1 & - & - & - \\
\hline Resistant & - & 1 & - & - \\
\hline Proteus mirabilis & 2 & 1 & - & 3 \\
\hline Haemophilus influenza & 1 & - & 2 & 1 \\
\hline Acinectobacter baumannii & 1 & 2 & - & - \\
\hline Campylobacter & - & 1 & - & - \\
\hline Enterobacter cloacae & - & - & 1 & - \\
\hline Brucella & - & - & 1 & - \\
\hline Serratia marcescens & - & - & 1 & - \\
\hline Treponema & - & - & 1 & - \\
\hline Klebsiella oxytoca & - & - & 1 & - \\
\hline Moraxella catarrhalis & - & - & 1 & - \\
\hline Citrobacter freundii & - & - & - & 1 \\
\hline Neisseria meningitidis & - & - & - & 1 \\
\hline Enterobacter aerogenes & - & - & - & 1 \\
\hline Acinetobacter & - & - & - & 1 \\
\hline Pasteurella multocida & - & - & - & 1 \\
\hline
\end{tabular}

ESBL, extended-spectrum $\beta$-lactamase.

mised status [12]. As cirrhotic patients are more likely to undergo invasive diagnostic or therapeutic procedures, which can alter the host's defense barrier, they are at increased risk of acquiring nosocomial infections [13].

The present study reported that the majority of the cirrhotic infections were CA $(49,60.5,56.6$, and $70.7 \%$ in $2008,2010,2012$, and 2014, respectively). In the literature, approximately $60 \%$ of bacterial infections in cirrhotic patients are CA and $40 \%$ are nosocomial [14]. Thus, the percentage in our study was relatively similar to that in the literature, except for the percentage in 2008.

In our study, the infections detected in cirrhotic patients were UTI $(32.5 \%)$, respiratory tract infection (29.3\%), SBP (26.1\%), and cellulitis (6.2\%). However, according to the literature, the most common infections in cirrhotic patients are SBP (25\%), UTI (20\%), pneumonia (15\%), bacteremia (12\%), and cellulitis $(2-11 \%)[5,8]$, which illustrates that the prevalence of each infection, in 
Table 4. Identification of gram-positive bacteria in cirrhotic patients

\begin{tabular}{lllll}
\hline & 2008 & 2010 & 2012 & 2014 \\
\hline $\begin{array}{l}\text { Staphylococcus aureus } \\
\quad \text { Methicillin-sensitive }\end{array}$ & 3 & 2 & - & 5 \\
$\quad$ Methicillin-resistant & 5 & 6 & 2 & 4 \\
Staphylococcus epidermidis & - & 1 & 1 & - \\
Staphylococcus capitis & - & - & - & 1 \\
\hline Enterococcus faecalis & & & & \\
$\quad$ Multisensitive & 1 & 3 & 4 & 3 \\
$\quad$ Resistant & 1 & - & - & - \\
Enterococcus faecium & & & & \\
$\quad$ Multisensitive & - & - & 1 & 1 \\
$\quad$ Resistant & - & - & 1 & 1 \\
Enterococcus cecorum & - & - & - & 1 \\
\hline Streptococcus viridans & 3 & 2 & - & 1 \\
Streptococcus pneumoniae & - & 2 & 1 & 3 \\
Streptococcus bovis & - & 2 & 3 & - \\
Streptococcus agalactiae & - & 1 & 1 & - \\
Streptococcus anginosus & - & - & 1 & - \\
\hline $\begin{array}{l}\text { Peptostreptococcus } \\
\text { Listeria }\end{array}$ & - & - & - & 1 \\
Corynebacterium diphteriae & - & - & 1 & - \\
Clostridium perfringens & - & - & - & 1 \\
Gemella morbillorum & - & - & - & 1 \\
\hline
\end{tabular}

this study, is about the same as that described in the literature so far, except for UTI and pneumonia.

In this study, a microbiological agent was identified in $32.4,59.3,53.5$, and $61.2 \%$ of infections in 2008,2010 , 2012 , and 2014, respectively. In the literature, infections are culture-positive in $50-70 \%$ of the cases, and the causative organisms of CA are gram-negative bacilli (GNB), especially $E$. coli, in about $60 \%$, gram-positive cocci (GPC), in about $30-35 \%$, and flora mixed in $5-10 \%[8$, 15]. In nosocomial infections, the pattern is different, with $60 \%$ for GPC and $30-35 \%$ for GNB, as a result of the use of previous antibiotic therapies, recent or current hospitalization, and therapeutic procedures $[6,8,15]$. So, with the exception of the year 2008 , the microbiological identification was higher than $50 \%$, which is in agreement with the published literature.

The present study identified $42.5,60.8,64.8$, and $67.6 \%$ GNB in the 4 interspersed years, consecutively, and the great majority of microbiological agents identified were E. coli. In 2012, 2 fungal infections (C. albicans) were detected: both were identified in UTI (1 nosocomial in a patient with a history of prostatic carcinoma; and $1 \mathrm{CA}$ in
Table 5. Antibiotics used

\begin{tabular}{|c|c|c|c|c|}
\hline & 2008 & 2010 & 2012 & 2014 \\
\hline \multicolumn{5}{|l|}{ Cephalosporin } \\
\hline Ceftriaxone & 34 & 33 & 31 & 59 \\
\hline Cefotaxime & 5 & 3 & - & 2 \\
\hline Cefazolin & 1 & 1 & 1 & 1 \\
\hline Cefuroxime & - & - & - & 1 \\
\hline \multicolumn{5}{|l|}{$\beta$-Lactams } \\
\hline Amoxicillin/clavulanic acid & 8 & 14 & 19 & 30 \\
\hline Flucloxacillin & 1 & 1 & 3 & 1 \\
\hline Piperacillin/tazobactam & 4 & 10 & 13 & 7 \\
\hline Ampicillin & - & - & - & 1 \\
\hline \multicolumn{5}{|l|}{ Quinolones } \\
\hline Ciprofloxacin & 4 & 7 & 6 & 0 \\
\hline Levofloxacin & 6 & 7 & 5 & 4 \\
\hline \multicolumn{5}{|l|}{ Macrolides } \\
\hline Azithromycin & - & - & - & 14 \\
\hline \multicolumn{5}{|l|}{ Aminoglycosides } \\
\hline Streptomycin & - & - & 1 & - \\
\hline Gentamicin & - & 1 & - & - \\
\hline \multicolumn{5}{|l|}{ Tetracycline } \\
\hline Doxycycline & - & - & 2 & - \\
\hline \multicolumn{5}{|l|}{ Sulfonamides } \\
\hline $\begin{array}{l}\text { Trimethoprim }+ \\
\text { sulfamethoxazole }\end{array}$ & - & 1 & 3 & 1 \\
\hline \multicolumn{5}{|l|}{ Carbapenems } \\
\hline Imipenem & 1 & 1 & - & - \\
\hline Meropenem & 2 & 1 & 1 & 1 \\
\hline \multicolumn{5}{|l|}{ Oxazolidinones } \\
\hline Linezolid $^{\mathrm{a}}$ & 2 & - & - & 1 \\
\hline \multicolumn{5}{|l|}{ Others } \\
\hline Clindamycin ${ }^{\mathrm{a}}$ & - & - & - & 3 \\
\hline Nitrofurantoin & - & - & 1 & - \\
\hline Metronidazole & - & - & - & 1 \\
\hline Quinine $^{\mathrm{a}}$ & - & - & 1 & - \\
\hline Vancomycin & - & - & - & 1 \\
\hline
\end{tabular}

a Antibiotics requiring hepatic dose adjustment if patients present Child-Pugh-Turcotte stage C.

a patient with a history of diabetes mellitus). According to the literature, in SBP and UTI, GNB (E. coli and Klebsiella) are predominant, while GPC are predominant in pneumonia (Streptococcus pneumoniae) and procedureassociated bacteremia (Staphylococcus aureus) $[8,15,16]$. Fungal infections (especially Candida species) are involved in up to $15 \%$ of severe cases of sepsis in cirrhosis $[8,15]$. 
Table 6. Antibiotic therapy for common community-acquired bacterial infections in cirrhosis

\begin{tabular}{|c|c|c|}
\hline SBP & $\begin{array}{l}\text { Escherichia coli } \\
\text { Streptococcus viridans } \\
\text { Enterobacter spp. }\end{array}$ & $\begin{array}{l}\text { Cefotaxime }(2 \mathrm{~g} / 6 \mathrm{~h} \text { or } 2 \mathrm{~g} / 12 \mathrm{~h} \mathrm{IV}) \\
\text { or amoxicillin/clavulanic acid }(1-0.2 \mathrm{~g} / 8 \mathrm{~h} \text {, then } \\
0.5-0.123 \mathrm{~g} / 8 \mathrm{~h} \mathrm{PO}) \\
\text { or ofloxacin }(400 \mathrm{mg} / 12 \mathrm{~h} \mathrm{PO}) \\
\text { or ciprofloxacin }(200 \mathrm{mg} / 12 \mathrm{~h} \mathrm{IV} \text {, then } 500 \mathrm{mg} / 12 \mathrm{~h} \mathrm{PO})\end{array}$ \\
\hline UTI & $\begin{array}{l}\text { Escherichia coli } \\
\text { Klebsiella pneumoniae } \\
\text { Enteroccus spp. }\end{array}$ & $\begin{array}{l}\text { Ciprofloxacin }(500 \mathrm{mg} / 12 \mathrm{~h} \mathrm{PO}) \\
\text { or cotrimoxazole }(160-800 \mathrm{mg} / 12 \mathrm{~h} \mathrm{PO}) \\
\text { or amoxicillin/clavulanic acid ( } 1-0.2 \mathrm{~g} / 8 \mathrm{~h} \mathrm{IV})\end{array}$ \\
\hline Pneumonia & $\begin{array}{l}\text { Streptococcus pneumoniae } \\
\text { Staphylococcus aureus } \\
\text { Escherichia coli }\end{array}$ & $\begin{array}{l}\text { Amoxicillin/clavulanic acid ( } 1-0.2 \mathrm{~g} / 8 \mathrm{~h} \mathrm{IV}) \\
\text { and macrolide or moxifloxacin }(400 \mathrm{mg} / 24 \mathrm{~h} \mathrm{PO})\end{array}$ \\
\hline Cellulitis & $\begin{array}{l}\text { Staphylococcus aureus } \\
\text { Streptococcus pyogenes } \\
\text { Klebsiella pneumoniae } \\
\text { Escherichia coli } \\
\text { Pseudomonas aeruginosa }\end{array}$ & Ceftazidime (2 g/8 h IV) + flucloxacillin (2 g/6 h IV) \\
\hline
\end{tabular}

SBP, spontaneous bacterial peritonitis; UTI, urinary tract infections; IV, intravenous; PO, per os.

In this study, 9.6\% multidrug-resistant bacteria were identified in $2008,18.5 \%$ in $2010,11.3 \%$ in 2012 , and $14.4 \%$ in 2014 , the majority being nosocomial $(85.7,70.6$, 75 , and $83.3 \%$ in $2008,2010,2012$, and 2014 , respectively). The burden of antimicrobial resistance among gramnegative pathogens has alarmingly increased worldwide over the last decade, showing resistance to at least 3 different classes of antimicrobials (Enterobacteriaceae [particularly Klebsiella pneumoniae], Pseudomonas aeruginosa, and Acinetobacter baumannii) [17]. Multidrug-resistant gram-negative pathogens have been associated with delays in an adequate antimicrobial treatment, leading to significant increases in mortality, along with prolonged length of in-hospital stay and excesses in health-care costs [17]. However, an increase in resistance among grampositive bacteria has also been detected, especially methicillin-resistant S. aureus and Enterococcus faecium [6]. In order to limit the prescription of antimicrobials and minimize resistance development, the stratification of patients at risk for multidrug-resistant pathogens is crucial but unfortunately remains a challenge in clinical practice [17].

In the present study, the following most common CA infections were identified: $66.7,45.5,54.2$, and $25 \%$ in SBP; 40, 58.1, 47.4, and 50\% in UTI; 41.7, 69.2, 57.1, and $72 \%$ in respiratory tract infections; and $100,100,87.5$, and $83.3 \%$ in cellulitis in $2008,2010,2012$, and 2014 , respectively. In these patients, empirical antibiotic therapy was successfully and correctly used in $94.2 \%$ in SBP, $47.9 \%$ in
UTI, $59.7 \%$ in respiratory tract infection, and $75.7 \%$ in cellulitis. Empirical antibiotic therapy was used correctly in more than $60 \%$ of all CA infections, with the exception of UTI. However, over the 4 interspersed years, the percentage of correct empirical antibiotic therapies in UTI increased $(25,50,50$, and $66.7 \%$ in $2008,2010,2012$, and 2014 , respectively). A high rate of suspicion and an early and appropriate initiation of antibiotics are needed in all patients with liver cirrhosis, correlating with a higher survival rate $[14,18]$. Indeed, an adequate empiric antimicrobial treatment will improve the prognosis [18]. Cirrhotic patients with sepsis and septic shock require emergency care during the early stage of sepsis (especially the first $6 \mathrm{~h}$ ) and an empiric antimicrobial treatment as soon as possible, because each hour of delay decreases the survival rate by $7.6 \%[15,18]$. Microbiological samples should be taken as early as possible when infection is suspected, before starting empiric antibiotics, which should be adapted to local epidemiology, prevalence of antibiotic resistance, and results of bacterial cultures [18]. Empiric antibiotic treatments for classical CA bacterial infections in cirrhosis are shown in Table 6.

In the present study, the majority of infections in cirrhotic patients occurred in CPT stage B $(42.7 \%)$ and stage $\mathrm{C}(39.3 \%)$, and the MELD score was $>15$ in the 4 interspersed years (16.8 in 2008, 18.9 in 2010, 16.4 in 2012, and 15.1 in 2014). According to the literature, the occurrence of bacterial infection in cirrhotic patients was associated with higher CPT or MELD scores (higher in CPT stage C 
and MELD >15) [19], showing that our results are in accordance with the literature.

The present study showed that most fatalities occurred in cirrhotic patients with more severe disease (CPT score B or C): 2008 (B: 20\%, C: 80\%); 2010 (B: 26.7\%, C: 73.3\%); 2012 (B: 33.3\%, C: 66.7\%); and 2014 (A: 3.5\%, B: 51.7\%, C: $44.8 \%)$. Elevated MELD $(16.8,18.9,16.4$, and 15.1 in $2008,2010,2012$, and 2014, respectively) was observed, which is in accordance with published work. Over time, mortality increased significantly $\left(\chi^{(3)}=10.393, p=0.016\right)$ by $7 \%$ in $2008,17.4 \%$ in $2010,15.2 \%$ in 2012 , and $25 \%$ in 2014 . We observed no statistically significant differences in mortality and age throughout the years: in 2008 $\left(\chi^{(34)}=21.354, p=0.955\right)$; in $2010\left(\chi^{(34)}=45.953, p=\right.$ $0.083)$; in $2012\left(\chi^{(38)}=53.301, p=0.051\right)$; and in 2014 $\left(\chi^{(38)}=37.600, p=0.488\right)$. On the contrary, regarding nosocomial infections, with the exception of the years 2012 and 2014, there were no statistical differences throughout the years, as is shown below in detail. Concerning the patients' age, statistical analysis proved that over the years the average age has significantly increased, from 63.6 years in 2008, 66.1 years in 2010, and 67.5 years in 2012 to 68.5 years in $2014\left(\chi^{(162)}=254.377, p=0.000\right)$.

Also, the data showed that there are no statistical differences related to mortality and nosocomial infections in the 2 first periods: in $2008\left(\chi^{(1)}=2.223, p=0.136\right)$ and in $2010\left(\chi^{(1)}=0.172, p=0.678\right)$. However, there are indeed statistical differences regarding the 2 variables in $2012\left(\chi^{(1)}=5.131, p=0.024\right)$ and in $2014\left(\chi^{(1)}=3.891\right.$, $p=0.049)$. This indicates that there seems to be a correlation between mortality and nosocomial infections, which can be explained by the fact that these are more resistant and, therefore, more challenging to treat. Indeed, these results can also be corroborated by the literature.

Furthermore, we checked whether there were statistical correlations between age and nosocomial infections and realized that there is no relation between the 2 in either year: in $2008\left(\chi^{(34)}=43.618, p=0.125\right)$; in 2010 $\left(\chi^{(34)}=42.377, p=0.153\right)$; in $2012\left(\chi^{(38)}=44.772, p=\right.$ $0.209)$; and in $2014\left(\chi^{(38)}=30.820, p=0.789\right)$.

Finally, we analyzed if the CPT and MELD scores are correlated with the mortality rate in order to understand if higher scores imply an unfavorable outcome. We observed that CPT scores significantly impacted mortality in only 2 periods (2010 and 2012): in $2008\left(\chi^{(2)}=3.261\right.$, $p=0.196)$; in $2010\left(\chi^{(2)}=8.510, p=0.014\right)$; in 2012 $\left(\chi^{(2)}=7.764, p=0.021\right)$; and in $2014\left(\chi^{(2)}=4.853, p=\right.$ 0.088 ). It is also important to point out that the only period to present a CPT score A was 2014, with 18 patients,

Bacterial Infections in Patients with Liver Cirrhosis contrarily to the other periods that presented only CPT stages B and C. Regarding the MELD score over the different periods, the data showed that there was a significant correlation between the variable and the mortality rate in 3 subsequent periods $(2010,2012$, and 2014): in $2008\left(\chi^{(2)}=0.459, p=0.795\right)$; in $2010\left(\chi^{(4)}=9.822, p=\right.$ $0.044)$; in $2012\left(\chi^{(3)}=8.739, p=0.033\right)$; and in 2014 $\left(\chi^{(4)}=10.697, p=0.030\right)$. Indeed, the lack of significance of the data in the first period (2008) may be related to a reduced sample: only 5 patients died. Again, the findings are in agreement with the published literature.

In the literature, severe cirrhosis (according to the CPT score) has higher rates of bacteremia (A: $3 \%, \mathrm{~B}: 23 \%$, C: $48 \%)$ with an overall mortality rate of $37-59 \%$ [16]. Infection-related mortality is high in patients with endstage liver disease, approaching $30 \%$ within 30 days and $66 \%$ within 1 year after hospital admission [3]. For this reason, infection is considered an important prognostic marker in patients with end-stage liver disease [3].

In our study, the MELD score was lower than in a previous article [10]: 16.8 in 2008, 18.9 in 2010, 16.4 in 2012, and 15.1 in 2014 versus 19 in the previous article. However, we found some similarities between the 2 articles: gram-negative bacteria were still more prevalent than gram-positive bacteria, the most common pathogen being E. coli, and CA infections were still more prevalent than nosocomial infections.

In conclusion, in the present study, we found that the MELD score was higher in patients who died (except in 2008), and this ratio is statistically significant. Although the increase in age does not statistically correlate with mortality, data show that the average age over the years has increased, indicating that most patients are now older, despite having a lower MELD average score over the years.

Another important factor that may also have influenced the increase in mortality are the comorbidities in patients with more advanced age (namely cardiovascular risk factors), which is a bias in this study, since these variables were not analyzed. Thus, we believe that comorbidities are a variable to be taken into account in a future project.

\section{Conclusion}

Infections are a major problem in patients with liver cirrhosis which causes multiple disturbances in the defense mechanisms and thus increases bacterial translocation $[14,16]$. With early diagnosis of infection and the 
appropriate antibiotic treatment, the mortality rate from bacterial infections in cirrhotic patients can decrease over the years [14].

Indeed, the majority of the cirrhotic infections were $\mathrm{CA}$, with a predominance of gram-negative bacteria. Instead, in nosocomial infections, there was a preponderance of multidrug-resistant bacteria. We observed an increased mortality rate in these patients when the decompensation occurred in the context of infection, and a correlation was detected between the mortality rate and more severe disease (CTP scores B and C and MELD > 15) in the 4 analyzed years. We also observed that the prevalence of multiresistant bacteria did not increase over the years, which shows that a good antibiotic policy can contain this flagellum. We believe that this study raises new issues for future research.

\section{Statement of Ethics}

This study did not require informed consent nor review/approval by the appropriate ethics committee.

\section{Disclosure Statement}

The authors have no conflicts of interest to declare.

\section{References}

1 Pop A, Andreica V. Infections and liver cirrhosis: a dangerous liaison. HVM Bioflux. 2015;7:264-70.

2 Ge PS, Runyon BA. Treatment of Patients with Cirrhosis. N Engl J Med. 2016 Aug; 375(8):767-77.

3 Bartoletti M, Giannella M, Lewis RE, Viale P. Bloodstream infections in patients with liver cirrhosis. Virulence. 2016 Apr;7(3):309-19.

4 Fernández J, Navasa M, Gómez J, Colmenero J, Vila J, Arroyo V, et al. Bacterial infections in cirrhosis: epidemiological changes with invasive procedures and norfloxacin prophylaxis. Hepatology. 2002 Jan;35(1):140-8

5 Carrola P, Militão I, Presa J. Infeções bacterianas no doente com cirrose hepática. GE J Port Gastrenterol. 2013;20(2):58-65.

6 Bunchorntavakul C, Chamroonkul N, Chavalitdhamrong D. Bacterial infectons in cirrhosis: A critical review and practical guidance. World J Hepatol. 2016 Feb;8(6):307-321.

7 Fernandez J, Arroyo V. Bacterial infections in cirrhosis: A growing problem with significant implications. Clin Liver Dis (Hoboken). 2013; 2(3):102-5.
8 Taneja SK, Dhiman RK. Prevention and management of bacterial infections in cirrhosis. Int J Hepatol. 2011;2011:784540.

9 Jalan R, Fernandez J, Wiest R, Schnabl B, Moreau R, Angeli P, et al. Bacterial infections in cirrhosis: a position statement based on the EASL Special Conference 2013. J Hepatol. 2014 Jun;60(6):1310-24.

10 Oliveira A, Branco JC, Barosa R, Rodrigues JA, Ramos L, Martins A, et al. Clinical and microbiological characteristics associated with mortality in spontaneous bacterial peritonitis: a multicenter cohort study. Eur J Gastroenterol Hepatol. 2016 Oct;28(10):121622.

11 Vitalis Z, Papp M. Bacterial infections in cirrhosis. In: Blackwell RM, Tyson AP, editors. Cirrhosis. Nova Science Publishers; 2014. pp. 63-87.

12 Hung TH, Tseng CW, Hsieh YH, Tseng KC, Tsai CC, Tsai CC. High mortality of pneumonia in cirrhotic patients with ascites. BMC Gastroenterol. 2013 Feb;13(1):25
13 Cheruvattath $\mathrm{R}$, Balan V. Infections in $\mathrm{Pa}$ tients With End-stage Liver Disease. J Clin Gastroenterol. 2007 Apr;41(4):403-11.

14 Lagadinou M, Gogos CA. Bacterial infections in cirrhotic patients: a retrospective epidemiologic study in a Greek university hospital. Clin Hepatol Hepat Rep. 2015;2(1):1.

15 Gustot T, Durand F, Lebrec D, Vincent JL, Moreau R. Severe sepsis in cirrhosis. Hepatology. 2009 Dec;50(6):2022-33.

16 Sevastianos VA, Dourakis SP. Pathogenesis, diagnosis and therapy of Infections complicating patients with chronic liver disease. Ann Gastroenterol. 2003;16(4):300-15.

17 Bassetti M, Carnelutti A, Peghin M. Patient specific risk stratification for antimicrobial resistance and possible treatment strategies in gram-negative bacterial infections. Expert Rev Anti Infect Ther. 2017 Jan;15(1):55-65.

18 Anastasiou J, Williams R. When to use antibiotics in the cirrhotic patient? The evidence base. Ann Gastroenterol. 2013;26(2):128-31.

19 Fagiuoli S, Colli A, Bruno R, Burra P, Craxi A, Gaeta GB, et al. Management of infections in cirrhotic patients: report of a consensus conference. Dig Liver Dis. 2014 Mar;46(3):20412. 